\title{
Patient's ability to consent during Inpatient Chemotherapy Treatment or Outpatient Radiotherapy Treatment in a tertiary care hospital of New Delhi, India
}

\author{
Article by Kavita Gupta \\ Ph.D. Clinical Research, Texila American University, India \\ E-mail: 16kavitagupta@texilaconnect.com
}

\begin{abstract}
Background: With the increase in the rate of cancer morbidity, there was a marked increase in the research area for the development of strategies for the management of cancer disease. However, this objective could only be achieved through various phase of clinical trials requiring humans as a subject of study. This raised an ethical issue as survey research conducted in the form of questionnaires consisted of the classic questions of anxiety, depression, psychosis, or agitation which may or may not suit the patient's ability to consent due to certain factors. In the present study, it was observed that how the patient and the care-giver supported in the completion of this research survey during the patient's inpatient chemotherapy or outpatient radiotherapy treatment.

Objectives: The primary objective of the present study was to determine and analyze the percentage of cancer patients enrolled in the study that required assistance either from the interviewer or from the care-givers in filling up of the QOL questionnaire form during the inpatient chemotherapy or outpatient radiotherapy sessions.

Methods: It was a cross-sectional, descriptive, hospital based evaluation study. Total duration of the study was 5 months (December 2015- April 2016), conducted in Medical and Radiation Oncology department of DR. B.L. Kapur Memorial Hospital, New Delhi, India. A convenience sample of 60 patients with cancer was selected. They were further divided into Chemotherapy group $(n=30)$ and Radiotherapy group $(n=30)$. Therefore, 30 cancer patients were on chemotherapy and the other 30 cancer patients were on radiotherapy. Data was obtained through direct interview, using validated Psychological intervention tool in the form of Questionnaire: WHOQOL-Bref Questionnaire, Zung Self-Rating Anxiety scale and Zung Self-Rating Depression scale.

Results: A total of 60 cancer patients were included in the study in which Chemotherapy group consisted of 30n cancer patients and Radiotherapy group consisted of 30n cancer patients. In the study, 6(20\%) were males and 24(80\%) were females in the chemotherapy group, and, 15(50\%) were males and $15(50 \%)$ were females in the radiotherapy group. Majority of the patients 32(53.34\%) were in the age range of 46-60 years. It was observed that maximum patients in chemotherapy, as well as, radiotherapy groups marked their ability to consent to participate in the study with less assistance from the researcher and the care-givers even during the treatment regimen.

Conclusion: It could be concluded from the results obtained from the study that the patients undergoing chemotherapy (66.6\%), or radiotherapy (76.7\%) sessions were able to consent freely without much assistance of the researcher or the care-giver. This further implied that in Indian scenario people are becoming more aware and thus, cooperated by participating in research studies so as to help manage the deadly disease "CANCER".
\end{abstract}

Keywords: Cancer, Patient's consent, Patient themselves, Assisted by researcher, Assisted by relatives. 
Texila International Journal of Clinical Research

Volume 3, Issue 2, Dec 2016

$\begin{array}{lll}\text { Abbreviations } & \\ \text { QOL } & : \text { Quality of life } \\ \text { QLQ } & : \text { Quality life Questionnaire } \\ \text { WHOQOL-Bref } & : \text { World Health Organization Quality of life assessment-a short brief version } \\ \text { ZSAS } & : \quad \text { Zung Self-Rating Anxiety scale } \\ \text { ZSDS } & : \text { Zung Self-Rating Depression scale } \\ \text { CT } & : \text { Chemotherapy Treatment } \\ \text { RT } & : \text { Radiotherapy Treatment } \\ \text { DOM } & : \text { Third Party Administrator } \\ \text { TPA } & : \text { Fine needle aspiration cytology } \\ \text { FNAC } & \text { Standard deviation. }\end{array}$

\section{Introduction}

According to the research, it was predicted that cancer incidence in India varied from 44-122 per 100,000 population in males and $52-128$ per 100,000 population in females ${ }^{[1]}$. It was estimated that, at present, nearly one million new cancer cases were being detected annually in the country ${ }^{[1]}$. For patients and their family, a diagnosis of cancer brings challenges to many aspects of daily life, with a major concern of being maintaining the highest quality of life possible during and after the experience ${ }^{[1]}$. Because of the aggressive cancer symptoms, patients with cancer and their families might face ongoing and challenging medical decisions that progressively and rapidly erode cognition ${ }^{[2]}$. Quality of Life (QOL) is a descriptive term that referred to people's emotional, social, and physical well-being as well as their ability to function in ordinary tasks of living ${ }^{[1]}$. The informed consent process consisted of 3 principles, viz., (1) Knowledge (the research proposal should state benefits and risks along with the alternative treatments and the outcome measures; (2) Voluntariness of the participant in which the pressure from the family is acceptable; (3) Competence where patient should understand the information disclosed ${ }^{[3]}$. Assessing a patient's medical decision-making capacity is a part of every medical research study ${ }^{[3]}$. The process is generally spontaneous and straightforward: during the performance of routine inpatient and outpatient visits, the researcher should confirm the ability of the cancer patients to understand their medical condition and options for care ${ }^{[3]}$. To perform this analysis of ability of a cancer patient to consent, a directed clinical interview is the best available option ${ }^{[3]}$. The clinical interview might consist of questions pertaining to case history from the care-givers or laboratory findings ${ }^{[3]}$. For some patients, however, the assessment may not be straightforward ${ }^{[3]}$. Currently, if a person failed to have the capacity to consent to treatment or research, substitute decision makers were employed (e.g., legal representatives or family members) ${ }^{[4]}$. Thus, a judgement by health care professionals that a person was not competent to provide informed consent might have a profound effect on the autonomy, or free will, of an individual ${ }^{[4]}$. Contemporary ideas on informed consent stem, in part, from the Nuremberg Code following the Second World War ${ }^{[4]}$. The code specified that consent to research should be voluntary and that participants should have free choice, adequate understanding, and the capacity to give consent ${ }^{[4]}$. 


\section{Aims}

The main objectives of the present study were:

i. To determine and analyze the ability of cancer patient to consent during inpatient chemotherapy treatment or outpatient radiotherapy treatment.

ii. To evaluate the percentage of cancer patients enrolled in the study that required assistance either from the interviewer or from the care-givers in filling up the QOL questionnaire form during the chemotherapy or radiotherapy sessions.

\section{Patients and methods}

During the conduct of the proposed study Ethical Procedures were respected. After obtaining authorized Ethical approval (Ref. No.: IRB/AARCE/5/DEC/2015/1 and dated December $7^{\text {th }}$, 2015) for the research study protocol from IRB and Ethical committee from Dr. B.L. Kapur Memorial Hospital, New Delhi, patients and their caregivers were approached in the inpatient as well as, outpatient clinic, where the purpose of the study was explained and they were invited to participate. Patients who agreed to participate were asked to sign an Informed Consent Form followed by the implementation of the instrument in the form of questionnaires.

The Research Design of the proposed approved study protocol included the following Sampling Technique:

1. Sample Size: The target population of patients undergoing Chemotherapy and Radiotherapy sessions.

Total participants $=60$ divided in the following pattern:

$\mathrm{N}$ (Chemotherapy treatment) $=30 \mathrm{n}$

$\mathrm{N}$ (Radiotherapy treatment) $=30 \mathrm{n}$

2. Eligibility criteria of the study:

\section{Inclusion criteria}

a. Breast cancer and sub-sites of head and neck tumors (e.g., nasopharyngeal, thyroid cancer, and parotid tumors)

b. Patients aged 18years or older,

c. Clinically diagnosed cases.

d. Cancer diagnosis confirmed by biopsy or FNAC,

e. Undergoing/during the treatment sessions

f. Voluntarily agreed to join the study.

g. Aware of diagnosis and predicted prognosis

\section{Exclusion criteria}

a. Inadequate clinical condition (ambulatory and terminally ill patients) to respond to an interview.

b. Have difficulty in understanding the questionnaire or communicating.

c. Patients who were serious and didn't give consent were excluded from the study.

d. Had a history of psychiatric disorder

e. Choice of chemotherapy drugs and their dosage, irradiation dosage.

3. The study involved primary research by Individual face-to-face interviews with 60 cancer patients undergoing either chemotherapy or radiotherapy treatment sessions through Structured and Validated WHOQOL-Bref Questionnaire that consisted of 26 questions on a five-point likert scale ${ }^{[5]}$, Zung Self Rating Anxiety Scale (ZSAS) that consisted of 20 questions on a fourpoint likert scale ${ }^{[6]}$, and Zung Self-rating Depression Scale (ZSDS) that consisted of 20 questions on a four-point likert scale ${ }^{[7]}$.

4. Eligible patients were identified through an institutional database or by referring physicians and were approached at their simulation appointment. After giving written informed consent from 
the patient or their caregivers, participants completed the assessment that included the self-report measures.

5. Patients who agreed to participate were asked to sign an informed consent and then the instruments in the form of questionnaire were applied. Subjective areas were covered using case histories.

6. Special care of the potential risks due to emotional distress was taken care of so that their dignity was not harmed.

7. A total of 5-6 interviews were performed per week, in the time and days most suitable for the clinic in the months of December 2015 to April 2016.

8. Each interview lasted approximately 25-60 minutes and all patients were thanked for their participation, valuable time and information in the end.

\section{Results}

\section{(a) Data collection}

Treatment-related symptoms were assessed using a series of interviews through standard questionnaires of WHOQOL-Bref, the core questionnaire, followed by Zung Self-rating Anxiety Scale (ZSAS) and Zung Self Rating Depression Scale (ZSDS) Questionnaires. The questionnaire was provided in a language that the patient could understand (English / Hindi) followed by interview of the patient who was either undergoing chemotherapy or radiotherapy treatment sessions ${ }^{[5,6,7]}$.

\section{(b) Statistical analyses}

The database and statistical analysis was performed using SPSS v.17 software. Measures such as mean, standard deviation, minimum and maximum range were developed from the continuous data. Relative frequency was calculated for discrete data. A p-value $<0.05$ was considered as statistical significant.

\section{Socio-demographic characteristics of the patients}

Table 1. Socio-demographic characteristics in the form of frequency and percentage of variables of the patients and correlation in the two groups, i.e., chemotherapy and radiotherapy

\begin{tabular}{|c|c|c|c|c|c|c|}
\hline \multirow{2}{*}{$\begin{array}{l}\text { S.No } \\
\text { • }\end{array}$} & \multirow[t]{2}{*}{ Variables } & \multirow[t]{2}{*}{ Parameters } & \multicolumn{2}{|c|}{ Chemotherapy } & \multicolumn{2}{|c|}{ Radiotherapy } \\
\hline & & & $\begin{array}{l}\text { Frequency } \\
\text { (n) }\end{array}$ & $\begin{array}{l}\text { Percentage } \\
\text { (\%) }\end{array}$ & $\begin{array}{l}\text { Frequency } \\
\text { (n) }\end{array}$ & $\begin{array}{l}\text { Percentage } \\
\text { (\%) }\end{array}$ \\
\hline 1. & Gender & $\begin{array}{l}\text { a. Male } \\
\text { b. Female }\end{array}$ & $\begin{array}{l}6 \\
24\end{array}$ & $\begin{array}{l}20.0 \% \\
80.0 \%\end{array}$ & $\begin{array}{l}15 \\
15\end{array}$ & $\begin{array}{l}50.0 \% \\
50.0 \%\end{array}$ \\
\hline 2. & Age & $\begin{array}{l}\text { a. } 18-30 \text { years } \\
\text { b. } 30 \\
\text { c. } 46 \\
\text { d. } 60\end{array}$ & $\begin{array}{l}5 \\
17 \\
8\end{array}$ & $\begin{array}{l}16.7 \% \\
56.7 \% \\
26.7 \%\end{array}$ & $\begin{array}{l}6 \\
15 \\
9\end{array}$ & $\begin{array}{l}20.0 \% \\
50.0 \% \\
30.0 \%\end{array}$ \\
\hline 3. & $\begin{array}{l}\text { Marital } \\
\text { status }\end{array}$ & $\begin{array}{l}\text { a. Unmarried } \\
\text { b. Married } \\
\text { c. Widow } \\
\text { d. Divorced/ } \\
\quad \text { Legally } \\
\text { separated } \\
\text { e. Others }\end{array}$ & 30 & $100.0 \%$ & $\begin{array}{l}1 \\
28 \\
1\end{array}$ & $\begin{array}{l}3.3 \% \\
93.3 \% \\
3.3 \%\end{array}$ \\
\hline 4. & $\begin{array}{l}\text { Educational } \\
\text { status }\end{array}$ & $\begin{array}{l}\text { a. Illiterate } \\
\text { b. Literate }\end{array}$ & 1 & $3.3 \%$ & 2 & $6.7 \%$ \\
\hline
\end{tabular}




\begin{tabular}{|c|c|c|c|c|c|c|}
\hline & & $\begin{array}{l}\text { i. Primary } \\
\text { ii. Secondary } \\
\text { iii. Tertiary }\end{array}$ & $\begin{array}{l}4 \\
10 \\
15\end{array}$ & $\begin{array}{l}13.3 \% \\
33.3 \% \\
50.0 \%\end{array}$ & $\begin{array}{l}5 \\
11 \\
12\end{array}$ & $\begin{array}{l}16.7 \% \\
36.7 \% \\
40.0 \%\end{array}$ \\
\hline 5. & Occupation & $\begin{array}{l}\text { a. Service } \\
\text { b. Business } \\
\text { c. Housewife } \\
\text { d. Freelancers } \\
\text { e. Pensioners } \\
\text { f. Domestic } \\
\text { duties } \\
\text { g. Cultivation }\end{array}$ & $\begin{array}{l}3 \\
3 \\
21 \\
3\end{array}$ & $\begin{array}{l}10.0 \% \\
10.0 \% \\
70.0 \% \\
10.0 \%\end{array}$ & $\begin{array}{l}10 \\
2 \\
11 \\
1 \\
4 \\
1 \\
\\
1\end{array}$ & $\begin{array}{l}33.3 \% \\
6.7 \% \\
36.7 \% \\
3.3 \% \\
13.3 \% \\
3.3 \% \\
3.3 \% \\
\end{array}$ \\
\hline 6. & $\begin{array}{l}\text { Type of } \\
\text { family }\end{array}$ & $\begin{array}{l}\text { a. Nuclear } \\
\text { b. Joint }\end{array}$ & $\begin{array}{l}16 \\
14\end{array}$ & $\begin{array}{l}53.3 \% \\
46.7 \%\end{array}$ & $\begin{array}{l}9 \\
21\end{array}$ & $\begin{array}{l}30.0 \% \\
70.0 \%\end{array}$ \\
\hline 7. & Cohabitants & $\begin{array}{l}\text { a. Living } \\
\text { alone } \\
\text { b. Living with } \\
\text { partner } \\
\text { c. Living with } \\
\text { partner and } \\
\text { children } \\
\text { d. Living with } \\
\text { children }\end{array}$ & $\begin{array}{l}15 \\
1\end{array}$ & $\begin{array}{l}50.0 \% \\
3.3 \% \\
46.7 \%\end{array}$ & $\begin{array}{l}4 \\
5\end{array}$ & $\begin{array}{l}13.3 \% \\
16.67 \% \\
70.0 \%\end{array}$ \\
\hline 8. & $\begin{array}{l}\text { Annual } \\
\text { income }\end{array}$ & $\begin{array}{l}\text { a. } N A \\
\text { b. } \leq 20 \\
\text { c. } 20 \\
\text { d. } 30 \\
\text { e. } 41 \\
\text { f. } \geq 84\end{array}$ & 22 & $73.3 \%$ & 11 & $36.7 \%$ \\
\hline 9. & $\begin{array}{l}\text { Place of } \\
\text { residence }\end{array}$ & $\begin{array}{l}\text { a. Small town } \\
\text { b. Big town }\end{array}$ & $\begin{array}{l}1 \\
29\end{array}$ & $\begin{array}{l}3.3 \% \\
96.7 \%\end{array}$ & $\begin{array}{l}8 \\
22\end{array}$ & $\begin{array}{l}26.7 \% \\
73.3 \%\end{array}$ \\
\hline
\end{tabular}

The mean age (SD) of the patients in Chemotherapy group: 54.37 (11.08) [Range: 32-75].

The mean age (SD) of the patients in Radiotherapy group: 54.21 (11.07) [Range: 32-75].

\section{Clinical characteristics of the patients}

Table 2: Clinicalcharacteristics in the form of frequency and percentage of variables of the patients and correlation in the two groups, i.e., chemotherapy or radiotherapy

\begin{tabular}{|l|l|l|l|l|l|l|}
\hline S.No. & Variables & Parameters & \multicolumn{2}{|l|}{ Chemotherapy } & \multicolumn{2}{l|}{ Radiotherapy } \\
\cline { 4 - 7 } & & $\begin{array}{l}\text { Frequency } \\
\text { (n) }\end{array}$ & $\begin{array}{l}\text { Percentage } \\
\text { (\%) }\end{array}$ & $\begin{array}{l}\text { Frequency } \\
\text { (n) }\end{array}$ & $\begin{array}{l}\text { Percentage } \\
\text { (\%) }\end{array}$ \\
\hline 1. & $\begin{array}{l}\text { Smoking } \\
\text { habit }\end{array}$ & a. Non-smoker & 27 & $90.0 \%$ & 27 & $90.0 \%$ \\
b. Ex-smoker & 3 & $10.0 \%$ & 4 & $10.0 \%$ \\
\hline 2. & $\begin{array}{l}\text { Drinking } \\
\text { habit }\end{array}$ & a. Non-drinker & 30 & $100.0 \%$ & 26 & $86.7 \%$
\end{tabular}


Texila International Journal of Clinical Research

Volume 3, Issue 2, Dec 2016

\begin{tabular}{|c|c|c|c|c|c|c|}
\hline & & b. Ex-drinker & & & 4 & $13.3 \%$ \\
\hline 3. & $\begin{array}{l}\text { Tobacco } \\
\text { use }\end{array}$ & $\begin{array}{l}\text { a. Yes } \\
\text { b. No } \\
\end{array}$ & $\begin{array}{l}1 \\
29 \\
\end{array}$ & $\begin{array}{l}3.3 \% \\
96.7 \% \\
\end{array}$ & $\begin{array}{l}7 \\
23 \\
\end{array}$ & $\begin{array}{l}23.3 \% \\
76.7 \% \\
\end{array}$ \\
\hline 4. & $\begin{array}{l}\text { Health } \\
\text { insurance }\end{array}$ & $\begin{array}{l}\text { a. Yes } \\
\text { b. No } \\
\end{array}$ & $\begin{array}{l}23 \\
7 \\
\end{array}$ & $\begin{array}{l}76.7 \% \\
23.3 \% \\
\end{array}$ & $\begin{array}{l}19 \\
11 \\
\end{array}$ & $\begin{array}{l}63.3 \% \\
36.7 \% \\
\end{array}$ \\
\hline 5. & $\begin{array}{l}\text { Type of } \\
\text { health } \\
\text { insurance }\end{array}$ & $\begin{array}{l}\text { a. Government } \\
\text { medically } \\
\text { insured } \\
\text { b. TPA } \\
\text { c. Cash }\end{array}$ & $\begin{array}{l}13 \\
7\end{array}$ & $\begin{array}{l}33.3 \% \\
43.3 \% \\
23.3 \%\end{array}$ & $\begin{array}{l}7 \\
11\end{array}$ & $\begin{array}{l}40.0 \% \\
23.3 \% \\
36.7 \%\end{array}$ \\
\hline 6. & $\begin{array}{l}\text { Support by } \\
\text { charity } \\
\text { organizatio } \\
n\end{array}$ & $\begin{array}{l}\text { a. Yes } \\
\text { b. No }\end{array}$ & 30 & $100.0 \%$ & 30 & $100 \%$ \\
\hline 7. & $\begin{array}{l}\text { Cancer } \\
\text { tumor } \\
\text { location }\end{array}$ & $\begin{array}{l}\text { a. Ca Breast } \\
\text { b. Ca Head } \\
\text { c. Ca Neck }\end{array}$ & $\begin{array}{l}1 \\
6\end{array}$ & $\begin{array}{l}76.7 \% \\
3.3 \% \\
20.0 \%\end{array}$ & $\begin{array}{l}5 \\
15\end{array}$ & $\begin{array}{l}33.3 \% \\
16.7 \% \\
50.0 \%\end{array}$ \\
\hline 8. & $\begin{array}{l}\text { Disease } \\
\text { acceptance }\end{array}$ & $\begin{array}{l}\text { a. Yes } \\
\text { b. No }\end{array}$ & $\begin{array}{l}23 \\
7\end{array}$ & $\begin{array}{l}76.7 \% \\
23.3 \%\end{array}$ & $\begin{array}{l}15 \\
15\end{array}$ & $\begin{array}{l}50.0 \% \\
50.0 \%\end{array}$ \\
\hline 9. & $\begin{array}{l}\text { Reproductiv } \\
\text { e age of } \\
\text { women }\end{array}$ & $\begin{array}{l}\text { a. Pre- } \\
\text { menopausal } \\
\text { b. Menopausal }\end{array}$ & $\begin{array}{l}10 \\
14 \\
\end{array}$ & $\begin{array}{l}33.3 \% \\
46.7 \% \\
\end{array}$ & 9 & $\begin{array}{l}30.0 \% \\
20.0 \% \\
\end{array}$ \\
\hline 10. & Cancer type & $\begin{array}{l}\text { a. } \text { Primary } \\
\text { cancer } \\
\text { b. Recurrent } \\
\text { cancer } \\
\end{array}$ & 30 & $100.0 \%$ & 30 & $100.0 \%$ \\
\hline 11. & $\begin{array}{l}\text { Co- } \\
\text { existence of } \\
\text { metastasis }\end{array}$ & $\begin{array}{l}\text { a. Yes } \\
\text { b. No }\end{array}$ & 8 & $\begin{array}{l}26.7 \% \\
73.4 \%\end{array}$ & 30 & $100.0 \%$ \\
\hline 12. & $\begin{array}{l}\text { Chemothera } \\
\text { py's cycle } \\
\text { during the } \\
\text { interview of } \\
\text { QLQ }\end{array}$ & b. $2^{\text {nd }}$ & $\begin{array}{l}2 \\
15\end{array}$ & $\begin{array}{l}6.7 \% \\
50.0 \%\end{array}$ & & \\
\hline
\end{tabular}




\begin{tabular}{|c|l|l|l|l|l|l|} 
& & $\begin{array}{l}\text { d. } 4^{\text {th }} \\
\text { e. } 5^{\text {th }} \\
\text { f. } 6^{\text {th }}\end{array}$ & $\begin{array}{l}6 \\
6\end{array}$ & $\begin{array}{l}20.0 \% \\
20.0 \% \\
3.3 \%\end{array}$ & \\
\hline 13 & $\begin{array}{l}\text { Radiotherap } \\
\text { y's cycle } \\
\text { during the } \\
\text { interview of } \\
\text { QLQ }\end{array}$ & a. $10^{\text {th }}-15^{\text {th }}$ & & & 5 & $16.7 \%$ \\
& $\begin{array}{l}\text { b. } 16^{\text {th }}-20^{\text {th }} \\
\text { c. } 21^{\text {st }}-25^{\text {th }} \\
\text { d. } 26^{\text {th }} 30^{\text {th }}\end{array}$ & & & & \\
& & & 21 & $70.0 \%$ \\
& & 1 & $10.0 \%$ \\
\end{tabular}

QOL domain scores for chemotherapy sessions $(n=30)$

Table 3. QOL domain scores for chemotherapy sessions $(\mathrm{n}=30)$

\begin{tabular}{|l|l|l|l|l|l|}
\hline $\begin{array}{l}\text { Domains for } \\
\text { QOL/Scale }\end{array}$ & $\begin{array}{l}\text { Minimum } \\
\text { possible } \\
\text { raw score }\end{array}$ & $\begin{array}{l}\text { Maximum } \\
\text { possible raw } \\
\text { score }\end{array}$ & $\begin{array}{l}\text { Mean of } \\
\text { raw score }\end{array}$ & $\begin{array}{l}\text { SD of raw } \\
\text { score }\end{array}$ & $\begin{array}{l}\text { Mean of Score } \\
\text { translated on } \\
\text { a scale of 100 }\end{array}$ \\
\hline Physical & 7 & 35 & 17.97 & 3.09 & 39.66 \\
\hline Psychological & 6 & 30 & 17.94 & 1.87 & 49.76 \\
\hline Social & 3 & 15 & 7.77 & 0.89 & 41.66 \\
\hline Environmental & 8 & 40 & 24.83 & 1.94 & 55.00 \\
\hline ZSAS Scores & 20 & 80 & 53.30 & 9.10 & 66.62 \\
\hline ZSDS Scores & 20 & 80 & 46.94 & 5.63 & 58.66 \\
\hline
\end{tabular}

In the chemotherapy group, the physical domain was the most affected domain, followed by social domain, psychological and environmental domain.

QOL domain scores for Radiotherapy sessions $(n=30)$

Table 4. QOL domain scores for radiotherapy sessions $(n=30)$

\begin{tabular}{|l|l|l|l|l|l|}
\hline $\begin{array}{l}\text { Domains for } \\
\text { QOL/Scale }\end{array}$ & $\begin{array}{l}\text { Minimum } \\
\text { possible raw } \\
\text { score }\end{array}$ & $\begin{array}{l}\text { Maximum } \\
\text { possible raw } \\
\text { score }\end{array}$ & $\begin{array}{l}\text { Mean of } \\
\text { raw score }\end{array}$ & $\begin{array}{l}\text { SD of } \\
\text { raw score }\end{array}$ & $\begin{array}{l}\text { Mean of } \\
\text { Score } \\
\text { translated on } \\
\text { a scale of 100 }\end{array}$ \\
\hline Physical & 7 & 35 & 17.37 & 4.18 & 37.13 \\
\hline Psychological & 6 & 30 & 17.74 & 2.78 & 49.10 \\
\hline Social & 3 & 15 & 7.77 & 1.25 & 40.73 \\
\hline Environmental & 8 & 40 & 25.10 & 2.35 & 55.26 \\
\hline ZSAS Scores & 20 & 80 & 43.17 & 8.04 & 53.95 \\
\hline ZSDS Scores & 20 & 80 & 41.70 & 6.05 & 52.12 \\
\hline
\end{tabular}

In the radiotherapy group, the physical domain was the most affected domain, followed by social domain, psychological and environmental domain.

Measuring ability of a cancer patient to consent in chemotherapy as well as, radiotherapy group while participating in QOL assessment 
Texila International Journal of Clinical Research

Volume 3, Issue 2, Dec 2016

Table 5. Measuring ability of a cancer patient to consent in chemotherapy as well as, radiotherapy group.

\begin{tabular}{|l|l|l|l|l|}
\hline \multirow{2}{*}{$\begin{array}{l}\text { Process of } \\
\text { Questionnaire } \\
\text { completion }\end{array}$} & $\begin{array}{l}\text { CHEMOTHERAPY } \\
\text { (n= 30) }\end{array}$ & $\begin{array}{l}\text { RADIOTHERAPY } \\
\text { (n= 30) }\end{array}$ \\
\cline { 2 - 5 } & $\mathbf{n}$ & $\begin{array}{l}\text { Percentag } \\
\text { e (\%) }\end{array}$ & $\mathbf{n}$ & $\begin{array}{l}\text { Percentag } \\
\text { e (\%) }\end{array}$ \\
\hline Patient themselves & 20 & $66.6 \%$ & 23 & $76.7 \%$ \\
\hline Assisted by relatives & 2 & $6.7 \%$ & 3 & $10.0 \%$ \\
\hline Assisted by researcher & 8 & $26.7 \%$ & 4 & $13.3 \%$ \\
\hline
\end{tabular}

It can be observed from table no. 3 and 4that in the chemotherapy group whose anxiety level (Mean= 66.62) and depression level (Mean= 58.66) as measured by ZSAS and ZSDS, respectively, patients were able to consent themselves 20(66.6\%), assisted by relatives/caregivers 2(6.7\%), and assisted by the researcher 8 (26.7\%) in order to, particpate in the research study entitled to "QOL of cancer patients during inpatient chemotherapy or outpatient radiotherapy".

On the other hand, in the radiotherapy group whose anxiety level (Mean= 53.95) and depression level (Mean= 52.12) as measured by ZSAS and ZSDS, respectively, patients were able to consent themselves 23(76.7\%), assisted by relatives/caregivers 3(10.0\%), and assisted by the researcher $4(13.3 \%)$ in order to, particpate in the research study entitled to "QOL of cancer patients during inpatient chemotherapy or outpatient radiotherapy”.

\section{Discussion}

The present study aimed at how the cancer patient undergoing either chemotherapy or radiotherapy sessions consented their ability to participate in the study entitled to "QOL of cancer patients during inpatient chemotherapy or outpatient radiotherapy treatment”. From the data retrieved it was observed that though cancer patients were suffering from the phase of anxiety and depression during the course of their treatment, yet maximum of the patients in both the treatment groups were able to consent their participation in the present research survey. All the studies published so far have included the standardized tools for measuring Medical competence to consent. However, in the present study, there was no such tool was utilized instead a general part is presented while assessing for the QOL of cancer patients during the chemotherapy or radiotherapy sessions.

\section{Conclusion}

Therefore, it could be concluded that Medical capacity to consent for participating in research study is an important aspect in cancer population as well. During the chemotherapy sessions or radiotherapy sessions, the cognitive ability gets affected. So, while conducting research survey it is important that the care-giver along with the researcher should be present with the cancer patient (subject) at the time of interview (research study).

\section{Future directions}

a. Larger sample size for the evaluation of the research study could be used.

b. Standardized assessment tools for medical capacity to consent in cancer patients could be used in order to, understand and analyze QOL of cancer patients during chemotherapy or radiotherapy treatment. 


\section{Limitations of the study}

a. Small sample size, i.e., Chemotherapy group $(n=30)$ and Radiotherapy group $(n=30)$ were included in the study.

b. Both the genders should have been equally included in the study so as to obtain gender specific significant differences.

\section{Footnotes}

Author's Contribution: 1- acquisition of data; 2- analysis and interpretation of data; 3- drafting of the manuscript; 4- critical revision of the manuscript for important intellectual content; 5 - statistical analysis; 6- administrative, technical and material supports.

Funding/Support: Self-funded.

\section{Acknowledgement}

The present study is a part of the research programme, “Assessment of Quality of Life of Adult Cancer Patients during inpatient Chemotherapy Treatment (CT), or outpatient Radiotherapy Treatment (RT) in a tertiary care hospital of New Delhi, India”. This research was supportedand assisted by at:

Department of Medical Oncology and Radiation Oncology, DR. B.L. Kapur Memorial Hospital, New Delhi, India.

\section{Under the Supervision of}

Dr. S. Hukku (H.O.D. of Radiation Oncology Department),

DR. B.L. Kapur Memorial Hospital,

New Delhi, India.

Dr. Amit Agarwal (H.O.D. of Medical Oncology Department),

DR. B.L. Kapur Memorial Hospital,

New Delhi, India.

\section{Under the Guidance of:}

Dr. Renita Bhamrah (Texila American University),

E-mail:darpreetrenita@gmail.com

\section{References}

[1]. Ananthanarayanan, R. M., Janardhan, V., Kannan, G., Nigam, N., Palani, T., Rani, V., et al. (2011). Assessment of quality of life of cancer patients in a tertiary care hospital of South India. Journal of Cancer Research and Therapeutics, 275-279. Available at:http://medind.nic.in/jat/t11/i3/jatt11i3p275.htm

[2]. Nichita, E. C., \& Buckley, P. F. (2007). Informed Consent and Competency: Doctor's Dilemma on the Consultation Liaison Service. Psychiatry (Edgmont), 4(3), 53-55.

https://www.ncbi.nlm.nih.gov/pmc/articles/PMC2922359/

[3]. Sturman, E. D. (2005). The capacity to consent to treatment and research: A review of standardized assessment tools. Clinical Psychology Review, 954 - 974.

http://users.phhp.ufl.edu/rbauer/forensic_neuropsychology/capacity_consent_treat_research_05.pdf

[4]. Triebel, K. L., Martin, R. C., Nabors, L. B., \& Marson, D. C. (2009). Medical decision-making capacity in patients with malignant glioma. Neurology, 73(24), 2086-2092.

http://doi.org/10.1212/WNL.0b013e3181c67bce

[5]. WHOQOL Group. (1998). Development of the World Health Organization WHOQOLBREF quality of life assessment. Psychol Med, 28:551-8.

[6]. Zung, W. W. K. (1971). A rating instrument for anxiety disorders. Psychosomatics, 12(6), 371-379. Available at: https://psychology-tools.com/zung-anxiety-scale/

[7]. Zung, W. W. K. (1965). A Self-Rating Depression Scale. (1965). Arch Gen Psychiatry, 12: 63-70. Available at: https://psychology-tools.com/zung-depression-scale/ 